\title{
Interannual variability in soil nitric oxide emissions over the United States as viewed from space
}

\author{
R. C. Hudman, A. R. Russell, L. C. Valin, and R. C. Cohen \\ Department of Chemistry, University of California Berkeley, Berkeley, CA, USA \\ Received: 16 March 2010 - Published in Atmos. Chem. Phys. Discuss.: 21 May 2010 \\ Revised: 14 September 2010 - Accepted: 20 September 2010 - Published: 20 October 2010
}

\begin{abstract}
We examine the interannual variability in the $\mathrm{NO}_{2}$ column over North America measured by the Ozone Monitoring Instrument (OMI) in 2005-2008. By comparison to a model of soil $\mathrm{NO}_{\mathrm{x}}$ emissions driven by the North American Regional Reanalysis precipitation and $0-10 \mathrm{~cm}$ soil temperature fields, we show the source of this observed interannual variability over much of the central United States in June is fertilizer application. We find that dry, warm conditions followed by convective precipitation induces pulsed emissions of $\mathrm{NO}_{\mathrm{x}}$ over the agricultural Great Plains. In June 2006 we infer a $50 \%$ increase in soil $\mathrm{NO}_{\mathrm{x}}$ emission and a $30 \%$ increase in the tropospheric $\mathrm{NO}_{2}$ column relative to the June 2005-2008 mean. In a case-study of fertilized corn and soybean fields over SE South Dakota, we find an associated rain-induced pulsing event reaching $4.6 \times 10^{15}$ molec $\mathrm{cm}^{-2}$, equivalent to a surface concentration of $\sim 2 \mathrm{ppbv}$. We calculate that soil $\mathrm{NO}_{\mathrm{x}}$ emissions resulted in a mean daily maximum 8-h ozone enhancement over the agricultural Great Plains of 5 ppbv in June 2006 (with predicted events reaching $16 \mathrm{ppbv}$ ) compared with a mean enhancement of $3 \mathrm{ppbv}$ for soil $\mathrm{NO}_{\mathrm{x}}$ in the years 2005-2008.
\end{abstract}

\section{Introduction}

Nitrogen oxide $\left(\mathrm{NO}_{\mathrm{x}}=\mathrm{NO}+\mathrm{NO}_{2}\right)$ emissions from soils $\left(\mathrm{S}_{\mathrm{NO}_{\mathrm{x}}}\right)$ affect local ozone air quality, secondary organic aerosol formation, ecosystem acidification and eutrophication, and the atmospheric lifetime of important greenhouse gases (e.g., $\mathrm{CO}_{2}$ and $\mathrm{CH}_{4}$ ) through its effect on $\mathrm{OH}$ (Intergovernmental Panel on Climate Change, 2007). Nitric oxide (NO) is produced as a by-product and obligatory intermedi-

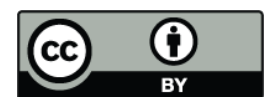

Correspondence to: R. C. Cohen (rccohen@berkeley.edu) ate of microbial nitrification and denitrification in soils (Conrad et al., 1996). Emissions vary greatly due to climatic and edaphic conditions, but the best correlations have been found with $\mathrm{N}$-availability, temperature and water-filled pore space, so that $\mathrm{S}_{\mathrm{NO}_{\mathrm{x}}}$ are highly dependent on local temperature, precipitation patterns, as well as fertilizer management practices (e.g., Williams and Fehsenfeld, 1991; van Dijk et al., 2002; Ludwig et al., 2001; Schindlbacher et al., 2004; Meixner and Yang, 2006; Stehfest and Bouwman, 2006). In addition to its effect on the chemistry of the atmosphere, $\mathrm{S}_{\mathrm{NO}_{\mathrm{x}}}$ are an indicator of the efficiency of soil $\mathrm{N}$ retention in both fertilized and natural ecosystems. A better understanding of factors affecting $\mathrm{N}$ retention is critical to developing effective and efficient methods of application of fertilizer $\mathrm{N}$ and for understanding the role of nitrogen in the carbon retention by biomass.

$\mathrm{S}_{\mathrm{NO}_{\mathrm{x}}}$ have been estimated on regional and global scales using empirical models (Yienger and Levy, 1995; Yan et al., 2005; Delon et al., 2007), process-based models (Potter et al., 1996; Parton et al., 2001) and scaling-up of field observation estimates (Davidson and Kingerlee, 1997) with global above-canopy estimates ranging from $4.7-13 \mathrm{Tg} \mathrm{N} \mathrm{yr}^{-1}$. At present, most atmospheric chemical transport models (CTM) employ the semi-empirical scheme developed by Yienger and Levy (1995) (YL), following Williams and Fehsenfeld (1991), which computes emissions as a function of vegetation type, temperature, precipitation, fertilizer application, and a canopy reduction factor (Bey et al., 2001; Steinkamp et al., 2009; Emmons et al., 2010). Recent comparisons of models and satellite observations reveal a factor of 2-4 underestimate in $\mathrm{S}_{\mathrm{NO}_{\mathrm{x}}}$ with respect to the $\mathrm{YL}$ a priori estimate (Martin et al., 2003; Jaegle et al., 2005; Wang et al., 2007; Boersma et al., 2008). For example, agricultural regions show strong disagreement between the a priori estimate and top-down inventory over the United States (0.41 vs. $1.0 \mathrm{Tg} \mathrm{N}_{\text {year }}{ }^{-1}$ ) (Jaegle et al., 2005) and in Mexico

Published by Copernicus Publications on behalf of the European Geosciences Union. 
(Boersma et al., 2008). To date revised inventories effectively assume a grid cell specific adjustment to source strength which is not understood at the process scale making predictions unreliable.

Surface observations of $\mathrm{S}_{\mathrm{NO}_{\mathrm{x}}}$ at the spatial scales needed to observe and infer mechanistic details affecting the emissions have sparse spatial coverage, so generalizing these results to regional and global budgets has proven difficult (e.g., Krupa et al., 2008; Ludwig et al., 2001; Conrad et al., 1996). To bridge the gap between global analyses that identify a need for enhanced emissions at regional scales (100 s of $\mathrm{km}$ ) and observations that can define processes affecting $\mathrm{NO}_{\mathrm{x}}$ at meter scales, Bertram et al. (2005) used daily $\mathrm{NO}_{2}$ columns retrieved from SCIAMACHY at $30 \mathrm{~km} \times 60 \mathrm{~km}$ to explore $\mathrm{S}_{\mathrm{NO}_{\mathrm{x}}}$ following $\mathrm{N}$-fertilization to dry agricultural fields. They found that the information contained in satellite observations is such that inverse modeling studies could tune mechanistic parameters that respond to climate and soil rather than a single parameter scale factor.

Here we build on these efforts to study links between climate and soil state variables and $\mathrm{S}_{\mathrm{NO}_{\mathrm{x}}}$. We use $\mathrm{NO}_{2}$ column densities from the Ozone Monitoring Instrument (OMI) (Boersma et al., 2002), interpreted with a model of $\mathrm{S}_{\mathrm{NO}_{\mathrm{x}}}$ (Yienger and Levy, 1995), driven by daily soil temperature and precipitation from the North American Regional Reanalysis (NARR) for 2005-2007, to show that satellite observations can detect interannual variability in $\mathrm{S}_{\mathrm{NO}_{\mathrm{x}}}$ over the United States. This interannual variability is a function of climate and soil state variables (e.g., top-soil temperature and the drying-wetting of soils). We then use GEOS-Chem, a chemical transport model, which represents the variability in $\mathrm{N}$ emissions to examine implications of this variability for ozone air quality.

\section{Model description}

\subsection{Soil $\mathrm{NO}_{\mathrm{x}}$ emissions}

We construct $\mathrm{S}_{\mathrm{NO}_{\mathrm{x}}}$ for the contiguous United States at $0.25^{\circ} \times 0.25^{\circ}$ resolution following Yienger and Levy (1995). The semi-empirical scheme computes $\mathrm{S}_{\mathrm{NO}_{\mathrm{x}}}$ as a function of vegetation type, temperature, precipitation history, fertilizer usage, and a canopy reduction factor. We use daily meteorological output from the National Center for Environmental Prediction North Atlantic Regional Reanalysis (NCEP/NARR), provided by the NOAA-CIRES Climate Diagnostics Center, Boulder, Colorado, USA (http: //www.cdc.noaa.gov/), for 2005-2008 for top-soil temperature (tsoil) and accumulated total precipitation (apcp) with a spatial resolution of $36 \mathrm{~km}$ for the continental United States (Mesinger et al., 2006). Chemical fertilizer usage is based on $0.5^{\circ} \times 0.5^{\circ}$ global dataset (Potter et al., 2010) and amounts to $70.2 \mathrm{Tg} \mathrm{Nyr}^{-1}$ globally and $12.0 \mathrm{Tg} \mathrm{N} \mathrm{yr}^{-1}$ over the region $\left[20^{\circ}-65^{\circ} \mathrm{N}, 135^{\circ}-70^{\circ} \mathrm{W}\right]$. We distribute fertilizer monthly by state based on Goebes et al. (2003), with exponential decay of fertilizer emissions ( $\tau=1.5$ months) (Matson et al., 1998). Manure is not included in the inventory. Vegetation type is taken from the NASA TERRA/MODIS HDF-EOS MOD12Q1 V004 (http://modis-land.gsfc.nasa. gov/landcover.htm) regridded to $0.25^{\circ} \times 0.25^{\circ}$ resolution with the mode of each grid box taken as overall land type. The canopy reduction follows Yienger and Levy (1995), Table 6. We increase the dry soil criteria used in pulsing in YL to $<2 \mathrm{~cm}$ precipitation in previous two weeks based on Bertram et al. (2005) and allow subsequent pulsing events of dry soils to be additive. Monthly mean emissions for 20052008 are shown in Fig. 1.

\subsection{GEOS-Chem}

The GEOS-Chem global three-dimensional model of tropospheric chemistry (version 8.02, http://acmg.seas.harvard. edu/geos/index.html) is driven by assimilated meteorological observations from the NASA Goddard Earth Observing System (GEOS-5). The model is applied to a global simulation of $\mathrm{O}_{3}-\mathrm{NO}_{\mathrm{x}}-\mathrm{VOC}$ chemistry including a fully coupled aerosol mechanism (Bey et al., 2001; Park et al., 2004). Meteorological fields in the GEOS-5 data have a temporal resolution of $6 \mathrm{~h}(3 \mathrm{~h}$ for surface variables and mixing depths) and a native horizontal resolution of $0.5^{\circ} \times 0.667^{\circ}$, with 72 vertical hybrid-eta levels between the surface and $0.01 \mathrm{hPa}$ (including 14 layers below $2 \mathrm{~km}$ ). We degrade the horizontal resolution of the meteorological fields to $2^{\circ} \times 2.5^{\circ}$ for input into GEOS-Chem. The simulations are conducted for 2005-2008 and are initialized on 1 January 2005 with GEOS-Chem fields generated by a 12-month spin-up simulation at $2^{\circ} \times 2.5^{\circ}$ resolution.

Global anthropogenic emissions in the model are drawn from EDGAR 3.2FT2000 inventory (Olivier et al., 2001) for the year 2000, implemented in GEOS-Chem by van Donkelaar et al. (2008). These are overwritten regionally with the US Environmental Protection Agency National Emission Inventory for 1999 (EPA-NEI99) NEI 99 with modifications described by Hudman et al. $(2007,2008)$, including a generalized 50\% decrease in $\mathrm{NO}_{\mathrm{x}}$ emissions from power plants and industry reflecting 1999-2004 reductions (Frost et al., 2006). We use Big Bend Regional Aerosol and Visibility Observational (BRAVO) Study Emissions Inventory for Mexico (Kuhns et al., 2003). Biomass burning emissions are from the interannual GFED2 inventory with monthly resolution (van der Werf et al., 2006; Randerson et al., 2007). $\mathrm{S}_{\mathrm{NO}_{\mathrm{x}}}$ are from the NARR-driven model described above. Emissions of $\mathrm{NO}_{\mathrm{x}}$ from lightning are linked to deep convection following the parameterization of Price and Rind (1992) with vertical profiles taken from Pickering et al. (1998). We use a $\mathrm{NO}_{\mathrm{x}}$ yield per flash of 125 moles in the tropics and 500 moles at northern mid-latitudes (north of $30^{\circ} \mathrm{N}$ ) (Hudman et al., 2007). Lightning emissions are scaled based on monthly 

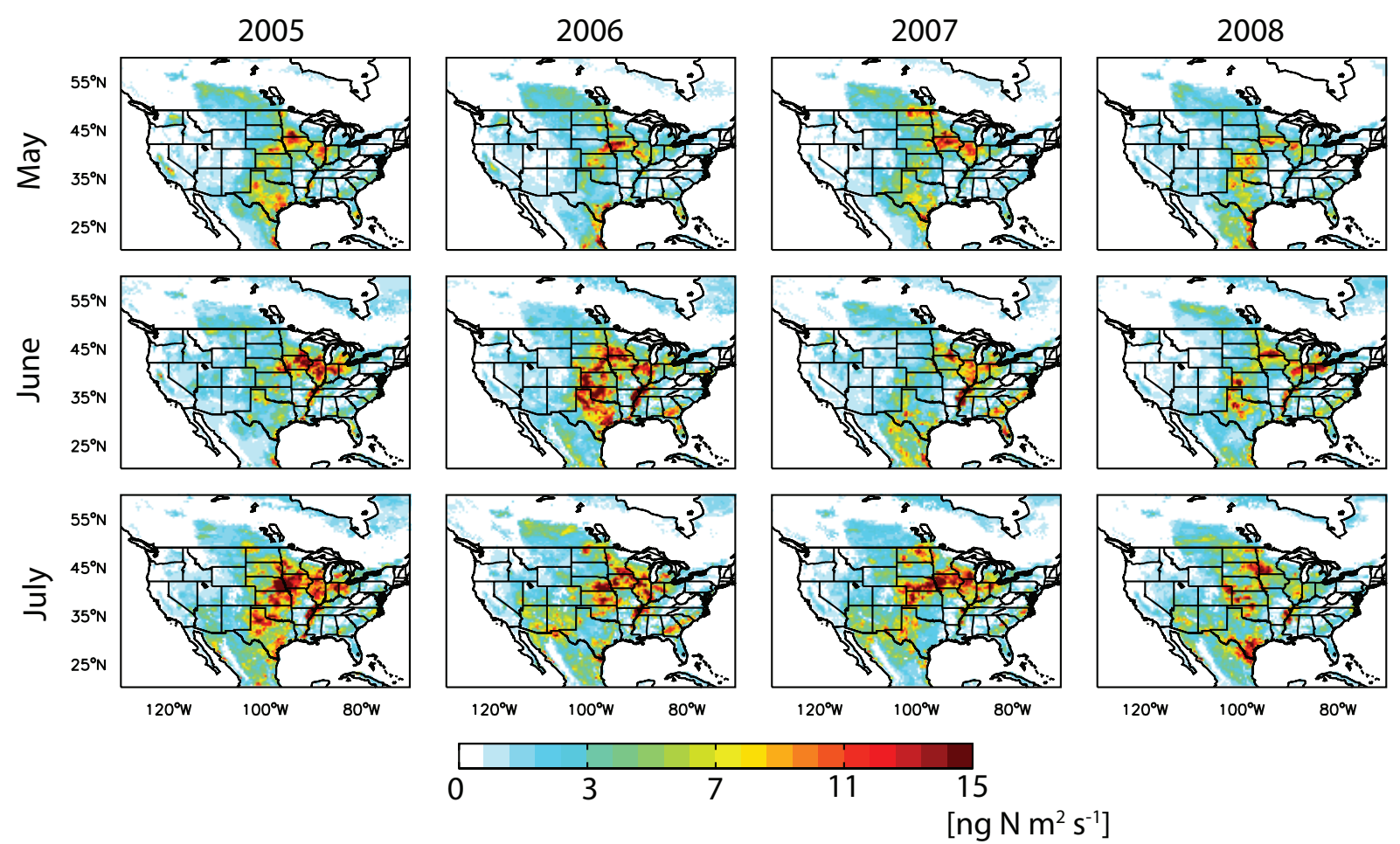

Fig. 1. Simulated monthly mean soil $\mathrm{NO}_{\mathrm{x}}$ emissions for $2005-2008$ at $0.25^{\circ} \times 0.25^{\circ}$ resolution. Emissions were derived using Yienger and Levy (1995) algorithm, with modifications as described in the text. The model is driven by daily precipitation and soil temperature from the North American Regional Reanalysis, NASA TERRA/MODIS HDF-EOS MOD12Q1 V004 land cover data, and fertilizer totals from Potter et al. (2010) with seasonality from Goebes et al. (2003) regridded to model resolution.

average rates from the lightning imaging sensor and optical transient detector satellite instruments (OTD/LIS) (Murray et al., 2010).

The boundary layer ventilation rate in the model has been evaluated through simulation of observed shapes of the mean vertical profiles of short-lived species including propane (Hudman et al., 2008), acetylene (Xiao et al., 2007), and formaldehyde (Millet et al., 2006). This point is further supported by analysis of $\mathrm{NO}_{\mathrm{x}}$ emissions vented to the free troposphere as $\mathrm{NO}_{\mathrm{y}}$ (observed $=16 \pm 10 \%$, modeled $=14 \pm 9 \%$ ) (Hudman et al., 2007) suggesting PBL exchange rates are not a dominate source of model error in the analysis of surface $\mathrm{NO}_{\mathrm{x}}$ sources.

\section{$3 \mathrm{OMI} \mathrm{NO}_{2}$ column measurements}

OMI is a nadir-viewing UV/Visible CCD spectrometer aboard the EOS-AURA satellite launched in July 2004 into a sun-synchronous orbit with a 13:38 local equator crossing time (Boersma et al., 2002). Spectra are recorded at 0.45$1 \mathrm{~nm}$ resolution in the $270-500 \mathrm{~nm}$ window, using an imaging array detector so that multiple locations on the Earth's surface are observed simultaneously. The $114^{\circ}$ field of view is distributed over 60 discrete viewing angles perpendicular to the flight direction yielding a $2600 \mathrm{~km}$ ground swath, allowing for daily global coverage, with pixel sizes that range from $13 \mathrm{~km} \times 24 \mathrm{~km}$ to $128 \mathrm{~km} \times 40 \mathrm{~km}$ at the edge of the sampling swath.

We use the standard product (Level 2, Version 1.0.5, Collection 3) available from the NASA Goddard Earth Sciences (GES) Data and Information Services Center DISC (http://disc.sci.gsfc.nasa.gov/Aura/data-holdings/ OMI/omno2_v003.shtml) and DOMINO product (Level 2, Version 1.0.3) available from KNMI (http://www.temis. nl/airpollution/no2.html). Here we use only data with cloud radiative fraction $<50 \%$. Details concerning the retrieval are provided in Boersma et al. (2002), Bucsela et al. (2006), Boersma et al. (2007) and Celarier et al. (2008). The limit of detection for OMI is approximately $5 \times 10^{14}$ molecules $\mathrm{NO}_{2} \mathrm{~cm}^{-2}$. For a $1 \mathrm{~km}$ uniformly mixed boundary layer this corresponds to a detection limit of $\sim 200$ pptv (Buscela et al., 2006).

Both products begin with the same $\mathrm{NO}_{2}$ slant column densities, determined using a non-linear least squares fit on the ratio of measured earthshine radiance to solar irradiance spectrums in the $405-465 \mathrm{~nm}$ window. Differences 
in the resulting tropospheric $\mathrm{NO}_{2}$ vertical column densities arise from differences in the methodology used to calculate the stratospheric component of the slant column and the tropospheric air mass factor, which converts the slant column to vertical column density. When inferred surface concentrations are compared to surface measurements over the Southeast United States, the standard product Version 1.0.5, Collection 3 have been shown to have a seasonal bias of $67-74 \%$ in summer and $-6 \%$ to $-1 \%$ in winter, while the DOMINO product version 1.0.2, Collection 3 is biased high by $21-33 \%$, with little seasonal variability (Lamsal et al., 2009). These biases are consistent year to year and thus do not affect relative differences of the same month over several years.

In Sect. 5, we show there can also be large differences between the retrievals on daily timescales in the vicinity of storm systems due to differences in the stratospheric subtraction. For the DOMINO product, the stratospheric $\mathrm{NO}_{2}$ field is estimated by assimilating $\mathrm{NO}_{2}$ slant columns into the TM4 chemistry-transport model. For the standard product, the stratospheric $\mathrm{NO}_{2}$ field is determined by masking regions where tropospheric $\mathrm{NO}_{2}$ columns are high. The remaining areas are used to generate a smoothed, interpolated stratospheric field using planetary wave- 2 analysis in $9^{\circ}$ wide zonal bands. A global, comprehensive validation of the stratospheric component in the vicinity of storms is warranted to reduce uncertainty in the individual retrievals both with respect to $\mathrm{S}_{\mathrm{NO}_{\mathrm{x}}}$ and to studies interested in lightning.

\section{Interannual variability in $\mathrm{OMI} \mathrm{NO}_{2}$ and Soil $\mathrm{NO}_{\mathrm{x}}$}

Figure 1 shows simulated mean $\mathrm{S}_{\mathrm{NO}_{\mathrm{x}}}$ over the United States and lower North America $\left(20^{\circ}-65^{\circ} \mathrm{N}, 135^{\circ}-70^{\circ} \mathrm{W}\right)$ for May-July 2005-2008. Average simulated yearly emissions are $0.62 \mathrm{Tg} \mathrm{Nyr}^{-1} \quad\left(0.12 \mathrm{Tg} \mathrm{Nyr}^{-1}\right.$ due to fertilizer application) with $62 \%$ of emissions occurring between MayAugust. At the low end, $\mathrm{S}_{\mathrm{NO}_{\mathrm{x}}}$ is $1-5 \mathrm{ng} \mathrm{N} \mathrm{m}^{-2} \mathrm{~s}^{-1}$ over natural grasslands of the Western United States. $\mathrm{S}_{\mathrm{NO}_{\mathrm{x}}}$ is largest over the agricultural Great Plains reflecting fertilizer $\mathrm{N}$ input and high temperatures, with peak monthly mean values reaching $>15 \mathrm{ng} \mathrm{N} \mathrm{m}^{-2} \mathrm{~s}^{-1}$. These values are consistent with mean summertime observations for fertilized fields over Iowa (18 $\mathrm{ng} \mathrm{N} \mathrm{m}^{-2} \mathrm{~s}^{-1}$ ) (Williams et al., 1992), Virginia $\left(9.7 \mathrm{ng} \mathrm{N} \mathrm{m}^{-2} \mathrm{~s}^{-1}\right)$ (Anderson and Levine, 1987), Texas grasses (12-43 $\mathrm{ng} \mathrm{N} \mathrm{m}^{-2} \mathrm{~s}^{-1}$ ) (Hutchinson and Brams, 1992), and for natural grasslands over Colorado (0.2$10 \mathrm{ng} \mathrm{N} \mathrm{m}^{-2} \mathrm{~s}^{-1}$ ) (Parrish et al., 1987; Williams et al., 1987, 1991; Martin et al., 1998).

Modeled emissions are variable day-to-day with a standard deviation comparable to mean values (not shown), reflecting synoptic variability in temperatures and pulsing associated with wetting and drying of soils. Mean emissions show little interannual variability for the months of May and July 2005-2008. Anomalously large emissions, however,
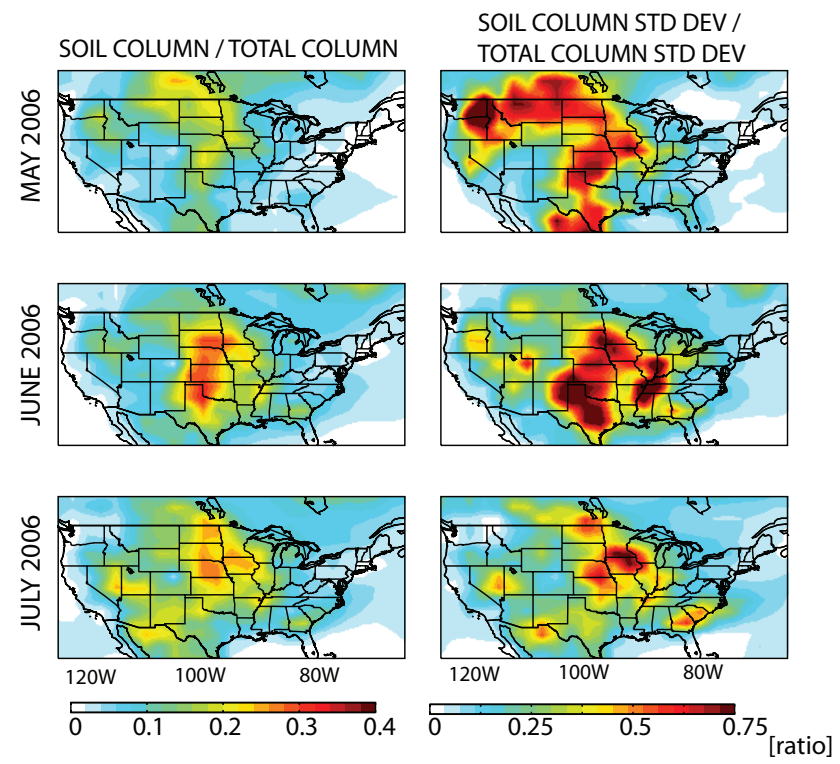

Fig. 2. Simulated contribution of soil $\mathrm{NO}_{\mathrm{x}}$ emissions to the monthly mean (left) and standard deviation (right) in tropospheric $\mathrm{NO}_{2}$ column over the United States using GEOS-Chem. The soil column is defined as the difference in the troposphereic $\mathrm{NO}_{2}$ column between a simulation with and without soil $\mathrm{NO}_{\mathrm{x}}$ emissions over the region $20-65^{\circ} \mathrm{N}, 135-70^{\circ} \mathrm{W}$.

are predicted in June 2006 over the agricultural Great Plains (Fig. 1). In the model the emissions appear as large pulses following dry, warm conditions.

To determine whether this interannual variability should be visible in the OMI tropospheric $\mathrm{NO}_{2}$ column, we examine the GEOS-Chem ratio of soil column $\mathrm{NO}_{2}$ to total tropospheric column $\mathrm{NO}_{2}$, where the soil column is defined as the difference between a simulation with and without $\mathrm{S}_{\mathrm{NO}_{\mathrm{x}}}$. Figure 2 shows the soil column is predicted to comprise between $15-40 \%$ of the total tropospheric $\mathrm{NO}_{2}$ column between May-July 2006 over the United States, with anthropogenic emissions, biomass burning, lightning, and background concentrations making up the remainder. Lightning was a smaller than average source in June 2006. A measure of the $\mathrm{S}_{\mathrm{NO}_{\mathrm{x}}}$ contribution to the tropospheric column variability can be diagnosed using the ratio of the standard deviation in the soil fraction to the total column standard deviation (Fig. 2). In the model $\mathrm{S}_{\mathrm{NO}_{\mathrm{x}}}$ governs $50-75 \%$ variability in the columns suggesting the $\mathrm{OMI} \mathrm{NO} \mathrm{N}_{2}$ record should reflect $\mathrm{S}_{\mathrm{NO}}$ pulses.

Figure 3 shows the $\mathrm{OMI} \mathrm{NO}_{2}$ monthly mean columns and deviations from the June 2005-2008 mean for $\mathrm{OMI} \mathrm{NO}_{2}$ column densities (standard product), temperature, precipitation, lightning counts, $\mathrm{S}_{\mathrm{NO}_{\mathrm{x}}}$ emissions, and GEOS-Chem $\mathrm{NO}_{2}$ columns (run without lighting emissions) for regions with mean June OMI $\mathrm{NO}_{2}$ column $>1.25 \times 10^{15}$ molec cm $^{-2}$. The presence of large anthropogenic emissions over the Eastern United States, the West Coast and individual 

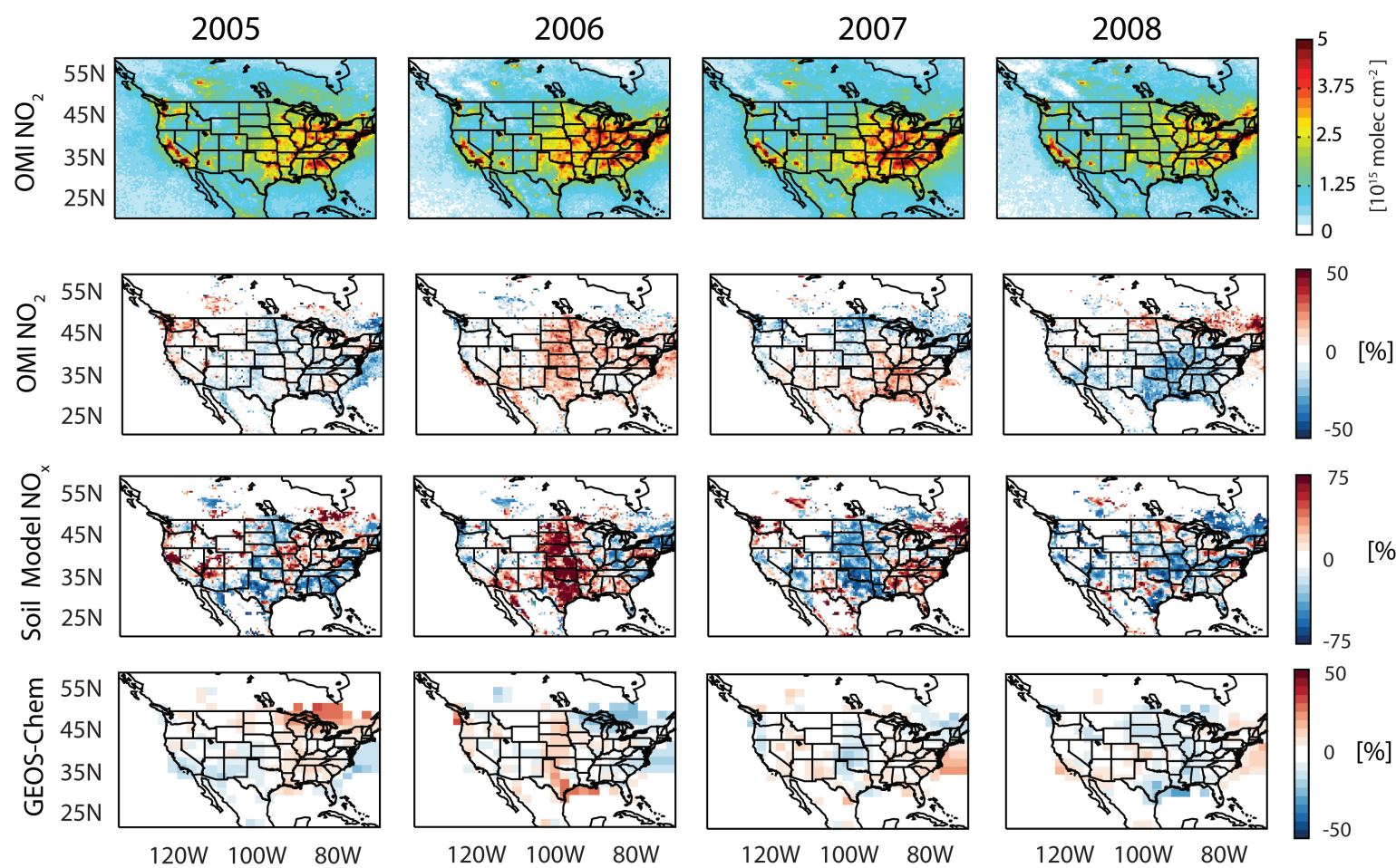

Fig. 3a. June mean $\mathrm{OMI} \mathrm{NO}_{2}$ column densities (top) are compared to mean anomalies for $\mathrm{OMI} \mathrm{NO}_{2}$ (middle) and Soil Model $\mathrm{NO}_{\mathrm{x}}$ emission (bottom), calculated as difference with June 2005-2008 mean. Only regions with mean June $\mathrm{OMI} \mathrm{NO}_{2}$ column $>1.25 \times 10^{15} \mathrm{molec}^{-2}$ are shown in anomaly plots. Color bar saturated at high and low end.

powerplants, scattered throughout the US are easily visible in maps of the $\mathrm{OMI} \mathrm{NO}_{2}$ tropospheric column. Over the agricultural Great Plains mean values range from $1.25-3 \times 10^{15}$ molec $\mathrm{cm}^{-2}$. In June 2006, OMI $\mathrm{NO}_{2}$ columns were up to $30 \%$ higher than average over the agricultural region in eastern North and South Dakota, Nebraska, Western Kansas and Northern Texas. Additionally, coastal Mexico and the Southeast United States show anomalously high columns. There are no significant differences in these figures if the DOMINO product is used instead of the standard product. The 2005-2008 $\mathrm{OMI} \mathrm{NO}_{2}$ anomalies over the agricultural Great Plains are spatially similar to those of modeled $\mathrm{S}_{\mathrm{NO}_{\mathrm{x}}}$ (Fig. 4). The anomaly is not due to an increase in energy use associated with warmer temperatures. There has been a decreasing trend in powerplant emissions in the month of June over the Great Plains of -4\% from 20052006, - 19\% from 2006-2007, and constant from 2007-2008 (data available at ftp://ftp.epa.gov/dmdnload/emissions/).

It is conceivable that the same storms that drive pulsed $\mathrm{S}_{\mathrm{NO}_{\mathrm{x}}}$ would also be associated with high lightning making it difficult to separate the effects of the two sources on the $\mathrm{NO}_{2}$ column. Figure $3 \mathrm{~b}$ shows monthly mean anomaly in daily flash counts from the National Lightning Detection Network for 2005-2007. June 2008 is not shown, as observed reported flash rates are 3-4X higher than previous years for reasons that are presently unclear but may be related to a change in al- gorithm. June 2006 had lower than average lightning counts suggesting lightning is not a source of higher than average $\mathrm{NO}_{2}$ in that month.

In the GEOS-Chem model, however, the June $\mathrm{NO}_{2}$ tropospheric column anomalies are incorrectly governed by lightning $\mathrm{NO}_{\mathrm{x}}$ emissions. The lightning parameterization currently assumes $\sim 20 \%$ of lightning $\mathrm{NO}_{\mathrm{x}}$ emissions are placed below $1 \mathrm{~km}$ (Pickering et al., 1998). More recent observations, however, suggest most lightning $\mathrm{NO}_{\mathrm{x}}$ originates and remains in the middle and upper troposphere, with only a small percentage $(\sim 2 \%)$ found near the surface (Ott et al., 2010). Since $\mathrm{NO}_{\mathrm{x}}$ is primarily $\mathrm{NO}$ at higher altitudes, it does not impact the tropospheric $\mathrm{NO}_{2}$ anomalies, consistent with OMI anomalies shown in Fig. 3a. GEOS-Chem modeled tropospheric $\mathrm{NO}_{2}$ anomalies for a simulation without lightning are consistent with OMI. This anomaly disappears when $\mathrm{S}_{\mathrm{NO}_{\mathrm{x}}}$ emissions are removed, adding further support to the conclusion that soil emissions are responsible for this variability and demonstrating that variations in transport of urban emissions are not responsible (Fig. 3a).

On average, June 2006 was warmer (by $0-2{ }^{\circ} \mathrm{C}$ ) and drier (by $0-50 \%$ ) over much of the central United States, while rains began earlier than normal over the Southwestern United States. These factors could lead to higher $\mathrm{NO}_{2}$ columns due to increased decomposition of PAN, and to higher boundary layer heights which increase the $\mathrm{NO}_{\mathrm{x}}$ lifetime, however, the 

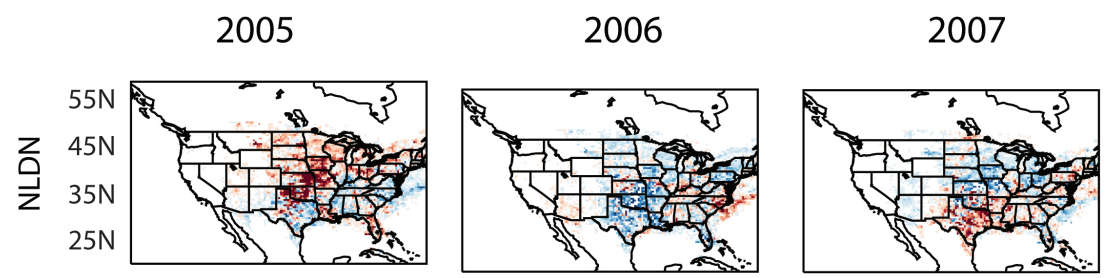

2008
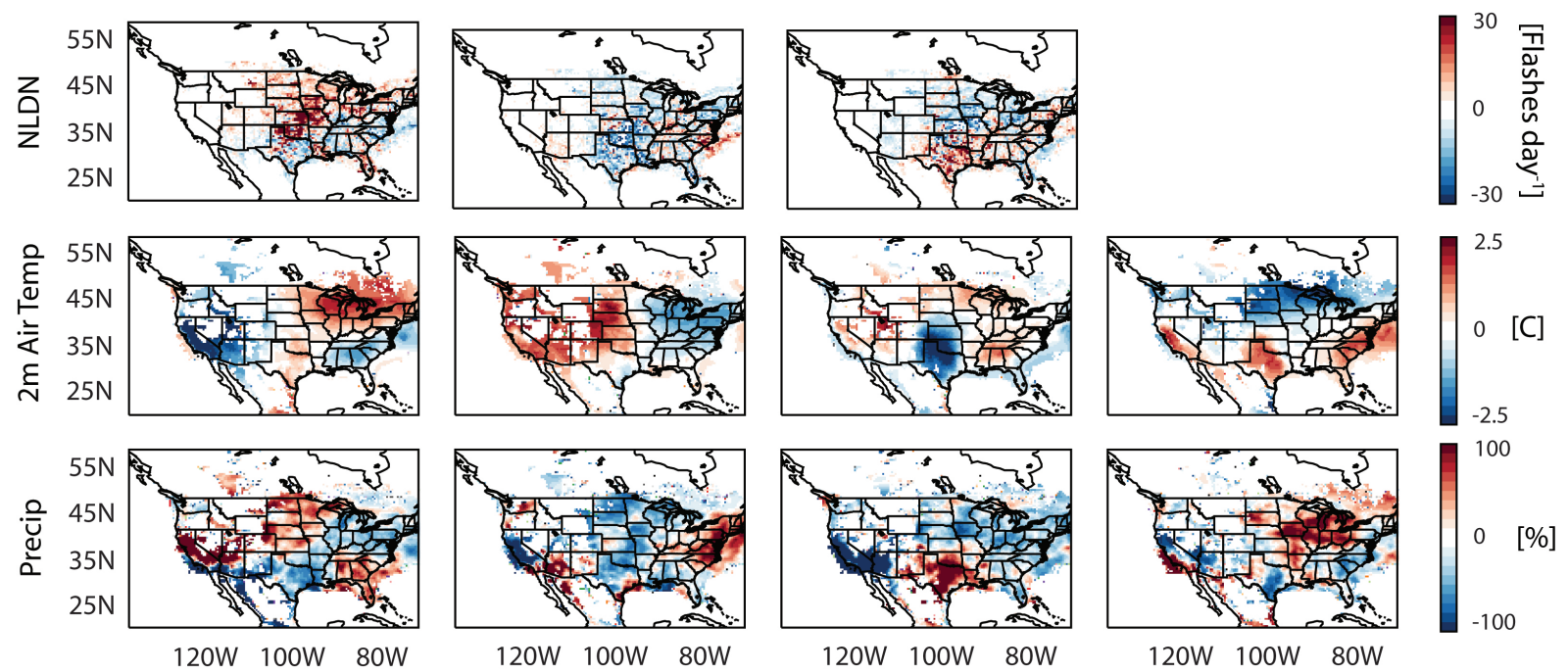

Fig. 3b. Same as Fig. 3a except for flash counts from the National Lightning Detection Network (NLDN) (mean daily flashes), Temperature $\left({ }^{\circ} \mathrm{C}\right)$, Precipitation (\%). NLDN flashes are X3 higher in 2008 than 2005-2007 for reasons that are unclear as such we take the anomaly from 2005-2007 mean.

spatial variability of the anomaly most closely matches that of the modeled $\mathrm{S}_{\mathrm{NO}_{\mathrm{x}}}$ suggesting $\mathrm{S}_{\mathrm{NO}_{\mathrm{x}}}$ governs the variability in the column over these regions (Fig. 4).

\section{Case-study of fertilizer induced pulsing over South Dakota in June 2006}

Figure 5 shows a timeseries of OMI tropospheric $\mathrm{NO}_{2}$ columns compared with predicted $\mathrm{S}_{\mathrm{NO}_{\mathrm{x}}}$ and daily precipitation over an area of rural SE South Dakota $\left(43-45^{\circ}\right.$ N, 98.75$96.25^{\circ} \mathrm{W}$; boxed region in Fig. 4). This region is primarily not irrigated $(<4 \%)$, and is planted with corn and soy beans as well as grassland (USDA, 2009, 2010). There is a low population density. According to our inventory, an average of $42 \mathrm{~kg} \mathrm{Nha}^{-1} \mathrm{yr}^{-1}$ are applied to the region yearly with $70 \%$ of that amount applied between March-June. Shown are OMI tropospheric $\mathrm{NO}_{2}$ columns for days with valid data coverage (cloud radiance fraction $<50 \%$ ) extending over more than $25 \%$ of the region. May-July OMI tropospheric $\mathrm{NO}_{2}$ standard product (DOMINO product statistics in parenthesis) columns range from $0.21-4.65 \times 10^{15}$ molec cm $\mathrm{cm}^{-2}(-0.50-$ $\left.4.16 \times 10^{15} \mathrm{molec} \mathrm{cm}^{-2}\right)$ with a mean of $2.02 \times 10^{15} \mathrm{molec}$ $\mathrm{cm}^{-2}\left(1.86 \times 10^{15} \mathrm{molec} \mathrm{cm}^{-2}\right)$ and standard deviation of $0.87 \times 10^{15}$ molec cm $\mathrm{cm}^{-2}\left(0.87 \times 10^{15}\right.$ molec $\left.\mathrm{cm}^{-2}\right)$. The modeled $\mathrm{S}_{\mathrm{NO}_{\mathrm{x}}}$ ranges from $1-50 \mathrm{ng} \mathrm{N} \mathrm{m}^{-2} \mathrm{~s}^{-1}$ during this time period.

The $\mathrm{S}_{\mathrm{NO}_{\mathrm{x}}}$ model predicts four $\mathrm{S}_{\mathrm{NO}_{\mathrm{x}}}$ pulses between MayJuly, each corresponding to peaks in the DOMINO OMI $\mathrm{NO}_{2}$ column, however not uniformly identified in the standard product retrieval. Our detailed analysis shows the primary difference between the appearance of peaks in these
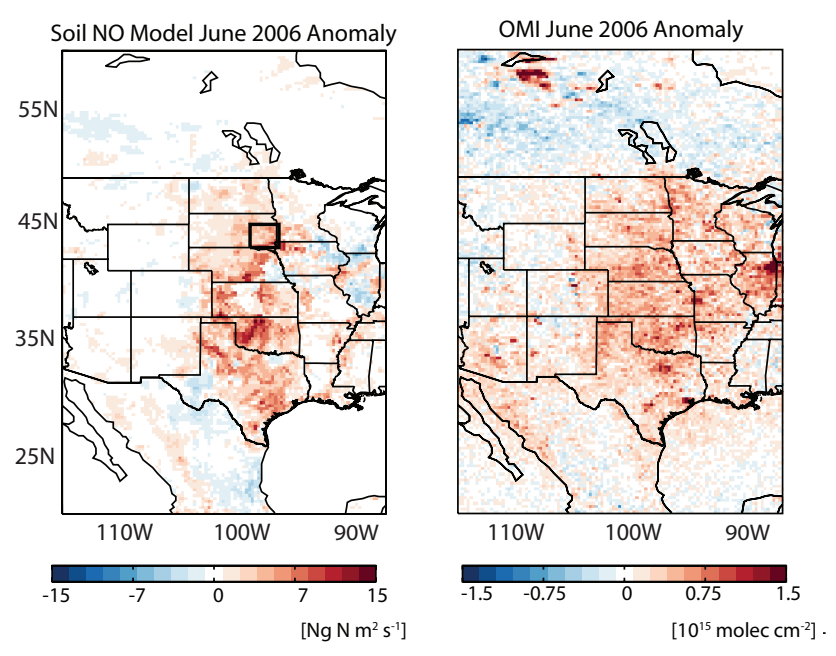

Fig. 4. The June 2006 modeled Soil $\mathrm{NO}_{\mathrm{x}}$ anomaly is compared to the OMI tropospheric $\mathrm{NO}_{2}$ column anomaly over the central United States. The anomalies are calculated as in Fig. 3a. Boxed region $\left(43-45^{\circ} \mathrm{N}, 98.75-96.25^{\circ} \mathrm{W}\right)$ shown is used in case-study in Sect. 5 of text.

retrievals is a result of the method each uses for stratospheric subtraction and that the differences are more important in the vicinity of storm systems. Future improvements in an analysis of $\mathrm{S}_{\mathrm{NO}_{\mathrm{x}}}$ pulses will require more comprehensive validation of the stratospheric and tropospheric $\mathrm{NO}_{2}$ products in the vicinity of storms. The largest predicted pulse in $\mathrm{S}_{\mathrm{NO}_{\mathrm{x}}}$ is 14-18 June. An associated peak is seen in both products on 15 June, with its peak reaching $4.6 \times 10^{15} \mathrm{molec} \mathrm{cm}^{-2} \mathrm{NO}_{2}$. Assuming a $1 \mathrm{~km} \mathrm{BL}$, this 


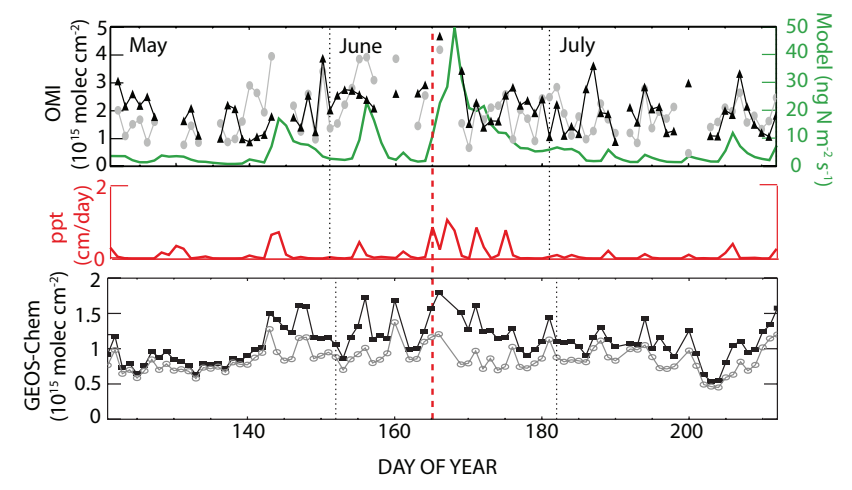

Fig. 5. May-July 2006 timeseries of soil NO pulsing events over rural South Dakota $\left(43-45^{\circ} \mathrm{N}, 98.75-96.25^{\circ} \mathrm{W}\right)$. OMI $\mathrm{NO}_{2}$ column densities (top) for the Standard Product (black triangles) and DOMINO Product (grey circles) are compared with predicted soil $\mathrm{NO}$ emissions (top, green) and precipitation (middle, red). GEOSChem $\mathrm{NO}_{2}$ column density with soil NO emissions included (bottom, black) and not included (bottom, gray).

pulse would correspond to a $\sim 2$ ppbv surface concentration over the region. The modeled soil $\mathrm{NO}_{\mathrm{x}}$ pulse begins on 14 June and peaks on 17 June, lags behind the observations by about 1 day. The discrepancy between modeled and observed timing is likely due to the model threshold for precipitation and our assumption that subsequent pulses are additive. Recent literature suggests that the magnitude of pulses is a function of dry-spell length rather than amount of rainfall and is of shorter duration than in the YL scheme (Yan et al., 2005). This timeseries suggests we can use OMI to test our understanding of pulsing triggers, lengths and magnitude for large pulsing events, and that cataloguing a large number of $\mathrm{S}_{\mathrm{NO}_{\mathrm{x}}}$ events will be a productive line of research.

The GEOS-Chem simulation with NARR $\mathrm{S}_{\mathrm{NO}_{\mathrm{x}}}$ predicts a tropospheric $\mathrm{NO}_{2}$ column mean (standard deviation) of $1.09 \times 10^{15} \mathrm{molec} \mathrm{cm}^{2} \mathrm{~s}^{-1}\left(0.28 \times 10^{15} \mathrm{molec} \mathrm{cm}^{2} \mathrm{~s}^{-1}\right)$, $\sim 40 \%$ lower than the retrievals (Fig. 5). The relative change in magnitude of the GEOS-Chem column during pulsing events $(\sim \mathrm{X} 2)$ is consistent with the OMI retrievals giving us confidence in our $\mathrm{S}_{\mathrm{NO}_{\mathrm{x}}}$ estimate. The largest variability in the modeled column is due to $\mathrm{S}_{\mathrm{NO}_{\mathrm{x}}}$, suggesting that $\mathrm{S}_{\mathrm{NO}_{\mathrm{x}}}$ rather than changes in anthropogenic emissions resulting from increased energy use or anthropogenic transport into the region leads to the June anomaly and $\mathrm{NO}_{2}$ peaks.

\section{Soil $\mathrm{NO}_{\mathrm{x}}$ impact on ozone air quality}

Figure 6 compares simulated June 2005-2008 mean daily 8-h maximum surface ozone enhancement due to soil $\mathrm{NO}_{\mathrm{x}}$ with those for June 2006. Surface enhancements range from 1-4 ppb over much of the central United States with largest enhancements over Mexico and western Texas. June 2006 enhancements due to $\mathrm{S}_{\mathrm{NO}_{\mathrm{x}}}$ are larger from 1-7 ppbv over

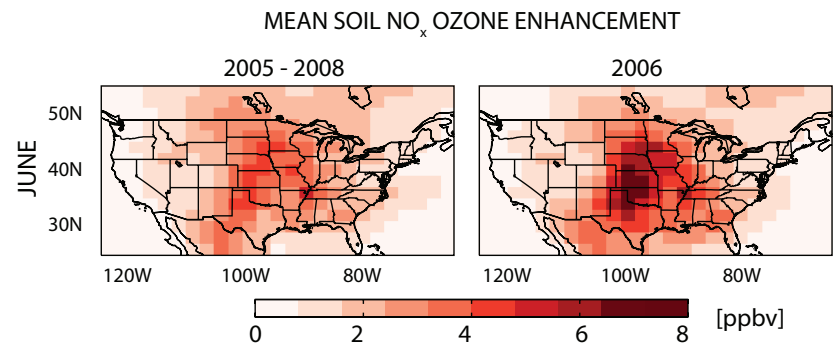

Fig. 6. June mean daily 8-h maximum ozone enhancement from soil $\mathrm{NO}_{\mathrm{x}}$ emissions for 2005 and 2007 (left) and 2006 (right) simulated using GEOS-Chem.

North America, with largest enhancements over the agricultural Great Plains, where the ozone enhancement due to soil increases from 3 to $5 \mathrm{ppbv}$. Predicted daily 8 -h maximum ozone events rise by as much as $16 \mathrm{ppbv}$ in 2006 . No events in 2005,2007 , or 2008 were larger than $12 \mathrm{ppbv}$.

Comparing simulated and observed 8-h maximum ozone concentrations for June 2006 over a semi-rural surface station in Sioux Falls, SD $\left(43.6^{\circ} \mathrm{N} 96.7^{\circ} \mathrm{W}\right)$ within the casestudy region, reveals an increase in ozone during the $\mathrm{NO}_{2}$ pulse event. Ozone increases in GEOS-Chem, both with and without $\mathrm{S}_{\mathrm{NO}_{\mathrm{x}}}$, due to the strong relationship between ozone and temperature/stagnation, illustrating the difficulty in attributing ozone to $\mathrm{S}_{\mathrm{NO}_{\mathrm{x}}}$ in observational datasets due to the correlation of temperature and $\mathrm{S}_{\mathrm{NO}_{\mathrm{x}}}$. We find, however, adding $\mathrm{S}_{\mathrm{NO}_{\mathrm{x}}}$ emissions removes a low bias and improves the daily correlation with observations throughout the month $(\mathrm{r}=0.38 \rightarrow 0.53)$, with maximum ozone enhancements due to $\mathrm{S}_{\mathrm{NO}_{\mathrm{x}}}$ in the model reaching $12 \mathrm{ppbv}$.

\section{Conclusions}

$\mathrm{NO}_{2}$ column densities from the Ozone Monitoring Instrument (OMI), together with a model of $\mathrm{S}_{\mathrm{NO}_{\mathrm{x}}}$, were used to examine the interannual variability of $\mathrm{S}_{\mathrm{NO}_{\mathrm{x}}}$ over the United States, its magnitude and pulsing behavior, and implications for ozone air quality. Anomolously large $\mathrm{S}_{\mathrm{NO}_{\mathrm{x}}}(\sim 50 \%$ greater than the June 2005-2008 mean) were predicted in June 2006 over the agricultural Great Plains due to raininduced pulsing, triggered by warmer $\left(+0-2{ }^{\circ} \mathrm{C}\right)$ and drier $(+0-50 \%)$ than average conditions over the region. Mean summertime tropospheric $\mathrm{NO}_{2}$ columns over the agricultural Great Plains ranged from $1.25-3 \times 10^{15} \mathrm{molec} \mathrm{cm}^{-2}$. In June 2006, columns were $30 \%$ higher with a spatial pattern consistent with our predicted $\mathrm{S}_{\mathrm{NO}_{\mathrm{x}}}$ anomaly confirming the presence of large interannual variation in $\mathrm{S}_{\mathrm{NO}_{\mathrm{x}}}$ emissions.

In a case-study over agricultural southeast South Dakota, we examined rain-induced pulsing events in May-July 2006. OMI tropospheric columns reached $4.6 \times 10^{15}$ molec cm $^{-2}$, equivalent to surface concentration of $\sim 2 \mathrm{ppbv}$. The model and observations have a similar number of peaks and 
the amplitudes of the peaks are similar, more so for the DOMINO product than for the standard product. The modeled peaks occur later than in observations and persist for longer, differences that suggest the model is not capturing the dynamics of pulsed $\mathrm{S}_{\mathrm{NO}_{\mathrm{x}}}$ properly.

Finally, we used the GEOS-Chem CTM driven by our NARR $\mathrm{S}_{\mathrm{NO}_{\mathrm{x}}}$ to examine implications for ozone air quality. We found that in June $2006 \mathrm{~S}_{\mathrm{NO}_{\mathrm{x}}}$ enhanced mean 8-h maximum surface ozone by $5 \mathrm{ppbv}$, compared with $3 \mathrm{ppbv}$ for 2005-2008, with daily ozone enhancements due to $\mathrm{S}_{\mathrm{NO}_{\mathrm{x}}}$ reaching up to $16 \mathrm{ppbv}$. These large enhancements suggest that reducing fertilizer use or increasing its efficiency would be a substantial benefit to air quality in the central United States.

Acknowledgements. This work was funded by NASA Grant \#NNX08AR13G. NLDN data provided by the NASA MSFC LIS Lightning Team via the Global Hydrology Resource Center (GHRC) located at the Global Hydrology and Climate Center (GHCC), Huntsville, Alabama through a license agreement with the Vaisala Group. The data available from the GHRC are restricted to MSFC LIS Science Team collaborators and to NASA EOS and TRMM investigators. We acknowledge the free use of tropospheric $\mathrm{NO}_{2}$ column data from the OMI sensor from www.temis.nl and http://disc.sci.gsfc.nasa.gov/Aura/data-holdings/ OMI/omno2_v003.shtml.

Edited by: A. Richter

\section{References}

Anderson, I. C. and Levine, J. S.: Simultaneous field measurements of biogenic emissions of nitric oxide and nitrous oxide, J. Geophys. Res., 92, 965-976, 1987.

Bertram, T. H., Heckel, A., Richter, A., Burrows, J. P., and Cohen, R. C.: Satellite measurements of daily variations in soil $\mathrm{NO}_{\mathrm{x}}$ emissions, Geophys. Res. Lett., 32, L24812, doi:10.1029/2005GL024640, 2005.

Bey, I., Jacob, D. J., Yantosca, R. M., Logan, J. A., Field, B. D., Fiore, A. M., Li, Q., Liu, H. Y., Mickley, L. J., and Schultz, M. G.: Global modeling of tropospheric chemistry with assimilated meteorology: Model description and evaluation, J. Geophys. Res., 106, 23073-23095, 2001.

Boersma, K. F., Bucsela, E. J., Brinksma, E. J., and Gleason, J. F.: $\mathrm{NO}_{2}$, in: OMI Algorithm Theoretical Basis Document, Vol. 4, OMI Trace Gas Algorithms, ATBD-OMI-04 (Version 2), 13-36, 2002.

Boersma, K. F., Eskes, H. J., Veefkind, J. P., Brinksma, E. J., van der A, R. J., Sneep, M., van den Oord, G. H. J., Levelt, P. F., Stammes, P., Gleason, J. F., and Bucsela, E. J.: Near-real time retrieval of tropospheric $\mathrm{NO}_{2}$ from OMI, Atmos. Chem. Phys., 7, 2103-2118, doi:10.5194/acp-7-2103-2007, 2007.

Boersma, K. F., Jacob, D. J. , Bucsela, E. J., Perring, A. E, Dirksen, R., van der A, R. J., Yantosca, R. M., Park, R. J., Wenig, M. O., Bertram, T. H., and Cohen, R. C.: Validation of OMI tropospheric $\mathrm{NO}_{2}$ observations during INTEX-B and application to constrain $\mathrm{NO}_{\mathrm{x}}$ emissions over the eastern United States and Mexico, Atmos. Environ., 42, 4480-4497, 2008.

Bucsela, E. J., Celarier, E. A., Wenig, M. O., Gleason, J. F., Veefkind, J. P., Boersma, K. F., and Brinksma, E. J.: Algorithm for $\mathrm{NO}_{2}$ vertical column retrieval from the ozone monitoring instrument, IEEE Trans. Geosci. Remote Sens., 44(5), 1245-1258, 2006.

Celarier, E. A., Brinksma, E. J., Gleason, J. F., Veefkind, J. P., Cede, A., Herman, J. R., Ionov, D., Goutail, F., Pommereau, J. P., Lambert, J. C., van Roozendael, M., Pinardi, G., Wittrock, F., Schonhardt, A., Richter, A., Ibrahim, O. W., Wagner, T., Bojkov, B., Mount, G., Spinei, E., Chen, C. M., Pongetti, T. J., Sander, S. P., Bucsela, E. J., Wenig, M. O., Swart, D. P. J., Volten, H., Kroon, M., and Levelt, P. F.: Validation of ozone monitoring instrument nitrogen dioxide columns, J. Geophys. Res., 113, D15S15, doi:10.1029/2007JD008908, 2008.

Conrad, R.: Soil microorganisms as controllers of atmospheric trace gases $\left(\mathrm{H}_{2}, \mathrm{CO}, \mathrm{CH}_{4}, \mathrm{OCS}, \mathrm{N}_{2} \mathrm{O}\right.$, and $\left.\mathrm{NO}\right)$, Microbiol. Rev., 60, 609-640, 1996.

Davidson, E. A. and Kingerlee, W.: A global inventory of nitric oxide emissions from soils, Nutr. Cycl. Agroecosys., 48, 37-50, 1997.

Delon C., Serca, D., Boissard, C., Dupont, R., Dutot, A., Laville, P., de Rosnay, P., and Delmas, R.: Soil NO emissions modeling using artificial neural network, Tellus B, 59B, 502-513, 2007.

Emmons, L. K., Walters, S., Hess, P. G., Lamarque, J.-F., Pfister, G. G., Fillmore, D., Granier, C., Guenther, A., Kinnison, D., Laepple, T., Orlando, J., Tie, X., Tyndall, G., Wiedinmyer, C., Baughcum, S. L., and Kloster, S.: Description and evaluation of the Model for Ozone and Related chemical Tracers, version 4 (MOZART-4), Geosci. Model Dev., 3, 43-67, 2010.

Frost, G. J., McKeen, S. A., Trainer, M., et al.: Effects of changing power plant $\mathrm{NO}_{\mathrm{x}}$ emissions on ozone in the eastern United States: Proof of concept, J. Geophys. Res., 111, D12306, doi:10.1029/2005JD006354, 2006.

Goebes, M. D., Strader, R., and Davidson, C.: An ammonia emission inventory for fertilizer application in the United States, Atmos. Environ., 37, 2539-2550, 2003.

Hudman, R. C., Jacob, D. J., Turquety, S., Leibensperger, E. M., Murray, L. T., Wu, S., Gilliland, A. B., Avery, M., Bertram, T. H., Brune, W., Cohen, R. C., Dibb, J. E., Flocke, F. M., Fried, A., Holloway, J., Neuman, J. A., Orville, R., Perring, A., Ren, X., Sachse, G. W., Singh, H. B., Swanson, A., and Wooldridge, P. J.: Surface and lightning sources of nitrogen oxides over the United States: Magnitudes, chemical evolution, and outflow, J. Geophys. Res., 112, D12S05, doi:10.1029/2006JD007912, 2007.

Hudman, R. C., Murray, L. T., Jacob, D. J., Millet, D. B., Turquety, S., Wu, S., Blake, D. R., Goldstein, A. H., Holloway, J., and Sachse, G. W.: Biogenic versus anthropogenic sources of CO in the United States, Geophys. Res. Lett., 35, L04801, doi:10.1029/2007GL032393, 2008.

Hutchinson, G. L. and Brams, E. A.: NO versus $\mathrm{N}_{2} \mathrm{O}$ emissions from an $\mathrm{NH}_{4}^{+}$-amended Bermuda grass pasture, J. Geophys. Res., 97, 9889-9896, 1992.

Intergovernmental Panel on Climate Change: Climate Change 2007: The Physical Science Basis, Contribution of Working Group I to the Fourth Assessment Report of the Intergovernmental Panel on Climate Change, edited by: Solomon, S., Qin, D., and Manning, M. et al., Cambridge Univ. Press, Cambridge, UK, 
2007

Jaegle, L., Steinberger, L., Martin, R. V., and Chance, K.: Global partitioning of $\mathrm{NO}_{\mathrm{x}}$ sources using satellite observations: Relative roles of fossil fuel combustion, biomass burning and soil emissions, Faraday Discuss., 130, 407-423, 2005.

Kuhns, H., Knipping, E. M., and Vukovich, J. M.: Development of a United States-Mexico Emissions Inventory for the Big Bend Regional Aerosol and Visibility Observational (BRAVO) Study, JAPCA J. Air Waste M., 55, 677-692, 2005.

Krupa, S., Bowersox, V., Lehmann, C., and Grantz, D.: Uncertainties in the Current Knowledge of Some Atmospheric Trace Gases Associated with U.S. Agriculture, JAPCA J. Air Waste M., 58, 986-993, 2008.

Lamsal, L. N., Martin, R. V., van Donkelaar, A., Celarier, V., Bucsela, E. J., Boersma, K. F., Dirksen, R., Luo, C., and Wang, Y.: Indirect validation of tropospheric nitrogen dioxide retrieved from the OMI satellite instrument: Insight into the seasonal variation of nitrogen oxides at northern midlatitudes, J. Geophys. Res., 115, D05302, doi:10.1029/2009JD013351, 2010.

Ludwig, J., Franz, F. X. , Vogel, B., and Forstner, J. : Soil-air exchange of nitric oxide: An overview of processes, environmental factors, and modelling studies, Biogeochemistry, 52, 225-257, 2001.

Martin, R. E., Scholes, M. C., Nosier, A. R., Ojima, D. S., Holland, E. A., and Parton, W. J.: Controls on annual emissions of nitric oxide from soils of the Colorado shortgrass steppe, Global Biogeochem. Cy., 12, 81-91, 1998.

Martin, R. V., Jacob, D. J., Chance, K., Kurosu, T. P., Palmer, P. I., and Evans, M. J.: Global inventory of nitrogen oxide emissions constrained by space-based observations of $\mathrm{NO}_{2}$ columns, J. Geophys. Res., 108(D17), 4537, doi:10.1029/2003JD003453, 2003

Matson, P. A., Naylor, R. L., and Ortiz Monasterio, I.: Integration of environmental, agronomic, and economic aspects of fertilizer management, Science, 280, 112-115, 1998.

Meixner, F. X. and Yang, W. X.: Biogenic emissions of nitric oxide and nitrous oxide from arid and semi-arid land, in: Dryland Ecohydrology, edited by: D'Odorico, P. and Porporato, A., Dordrecht, Berlin Heidelberg New York, ISBN: 1-4020-4261-2, 233-255, 2006

Mesinger, F., DiMego, G., Kalnay, E., et al.: North American Regional Reanalysis, B. Am. Meteorol. Soc., 87, 343-360, 2006.

Mijling, B., van der A, R. J., Boersma, K. F., Van Roozendael, M., De Smedt, I., and Kelder, H. M.: Reductions of $\mathrm{NO}_{2}$ detected from space during the 2008 Beijing Olympic Games, Geophys. Res. Lett., 36, L13801, doi:10.1029/2009GL038943, 2009.

Millet, D. B., Jacob, D. J., Turquety, S., Hudman, R. C., Wu, S., Fried, A., Walega, J., Heikes, B. G., Blake, D. R., Singh, H. B., Anderson, B. E., and Clarke, A. D.: Formaldehyde distribution over North America: implications for satellite retrievals of formaldehyde columns and isoprene emission, J. Geophys. Res., 111, D24S02, doi:10.1029/2005JD006853, 2006.

Murray, L. T.: Spatiotemporally constraining the lightning flash rate parameterization to satellite observations in a chemical transport model and its impact on tropospheric ozone variability, in preparation, 2010.

Olivier, J. G. J., Berdowski, J. J. M., Peters, J. A. H. W., Bakker, J., Visschedijk, A. J. H., and Bloos, J. P. J.: Applications of EDGAR, Including a description of EDGAR 3.2: refer- ence database with trend data for 1970-1995, RIVM, Bilthoven, RIVM report 773301 001/NRP report 410200 051, 2001.

Park, R. J., Jacob, D. J. , Field, B. D., Yantosca, R. M., and Chin, M.: Natural and transboundary pollution influences on sulfate-nitrate-ammonium aerosols in the United States: Implications for policy, J. Geophys. Res., 109, D15204, doi:10.1029/2003JD004473, 2004.

Parrish, D. D., Williams, E. J., Fahey, D. W., and Fehsenfeld, F. C.: Measurement of nitrogen oxide fluxes from softs: Intercomparison of enclosure and gradient measurement techniques, J. Geophys. Res., 92, 2165-2171, 1987.

Parton, W. J., Holland, E. A., Del Grosso, S. J., Hartman, M. D., Martin, R. E., Mosier, A. R., Ojima, D. S., and Schimel, D. S. Generalized model for $\mathrm{NO}_{\mathrm{x}}$ and $\mathrm{N} 2 \mathrm{O}$ emissions from soils, J. Geophys. Res., 106, 17403-17419, 2001.

Pickering, K. E., Wang, Y., Tao, W.-K., Price, C., and Muller, J.F.: Vertical distributions of lightning $\mathrm{NO}_{\mathrm{X}}$ for use in regional and global chemical transport models, J. Geophys. Res., 103(D23), 31203-31216, 1998.

Potter, C. S., Matson, P. A., Vitousek, P. M., and Davidson, E. A.: Process modeling of controls on nitrogen trace gas emissions from soils worldwide, J. Geophys. Res., 101(D1), 1361-1377, 1996.

Potter, P., Ramankutty, N., Bennett, E., and Donner, S.: Characterizing the Spatial Patterns of Global Fertilizer Application and Manure Production, Earth Interact., in press, 2010.

Price, C. and Rind, D.: A simple lightning parameterization for calculating global lightning distributions, J. Geophys. Res., 97, 9919-9933, 1992.

Randerson, J. T., van der Werf, G. R., Giglio, L., Collatz, G. J., and Kasibhatla, P. S.: Global Fire Emissions Database, Version 2 (GFEDv2.1), Data set, from Oak Ridge National Laboratory Distributed Active Archive Center, Oak Ridge, Tennessee, U.S.A., doi:10.3334/ORNLDAAC/849, available at: http://daac. ornl.gov/, 2007.

Schindlbacher, A., Zechmeister-Boltenstern, S., and ButterbachBahl, K.: Effects of soil moisture and temperature on $\mathrm{NO}, \mathrm{NO}_{2}$, and $\mathrm{N}_{2} \mathrm{O}$ emissions from European forest soils, J. Geophys. Res., 109, D17302, doi:10.1029/2004JD004590, 2004.

Stehfest, E. and Bouwman, L.: $\mathrm{N}_{2} \mathrm{O}$ and $\mathrm{NO}$ emission from agricultural fields and soils under natural vegetation: summarizing available measurement data and modeling of global annual emissions, Nutr. Cycl. Agroecosys., 74, 207-228, doi:10.1007/s10705-006-9000-7, 2006.

Steinkamp, J., Ganzeveld, L. N., Wilcke, W., and Lawrence, M. G.: Influence of modelled soil biogenic NO emissions on related trace gases and the atmospheric oxidizing efficiency, Atmos. Chem. Phys., 9, 2663-2677, doi:10.5194/acp-9-2663-2009, 2009.

U.S. Department of Agriculture: National Agricultural Statistics Service, Research and Development Division, 2009 Cropland Data Layer, available at: http://www.nass.usda.gov/research/ Cropland/SARS1a.htm, 2010.

U.S. Department of Agriculture: 2007 Census of Agriculture (Map available at: http://www.agcensus.usda.gov/ Publications/2007/Online_Highlights/Ag_Atlas_Maps/Farms/ Land_in_Farms_and_Land_Use/07-M082.asp), 2009.

van der Werf, G. R., Randerson, J. T., Giglio, L., Collatz, G. J., Kasibhatla, P. S., and Arellano Jr., A. F.: Interannual variabil- 
ity in global biomass burning emissions from 1997 to 2004, Atmos. Chem. Phys., 6, 3423-3441, doi:10.5194/acp-6-3423-2006, 2006.

van Dijk, S. M., Gut, A. , Kirkman, G. A., Meixner, F. X., Andreae, M. O., and Gomes, B. M.: Biogenic NO emissions from forest and pasture soils: Relating laboratory studies to field measurements, J. Geophys. Res., 107(D20), 8058, doi:10.1029/2001JD000358, 2002.

van Donkelaar, A., Martin, R. V., Leaitch, W. R., Macdonald, A. M., Walker, T. W., Streets, D. G., Zhang, Q., Dunlea, E. J., Jimenez, J. L., Dibb, J. E., Huey, L. G., Weber, R., and Andreae, M. O.: Analysis of aircraft and satellite measurements from the Intercontinental Chemical Transport Experiment (INTEX-B) to quantify long-range transport of East Asian sulfur to Canada, Atmos. Chem. Phys., 8, 2999-3014, doi:10.5194/acp-8-2999-2008, 2008.

Wang, Y. X., McElroy, M. B., Martin, R. V., Streets, D. G., Zhang, Q., and Fu, T.-M.: Seasonal variability of $\mathrm{NO}_{\mathrm{x}}$ emissions over east China constrained by satellite observations: Implications for combustion and microbial sources, J. Geophys. Res., 112, D06301, doi:10.1029/2006JD007538, 2007.
Williams, E. J., Parrish, D. D., and Fehsenfeld, F. C.: Determination of nitrogen oxide emissions from soils: Results from a grassland site in Colorado, United States, J. Geophys. Res., 92(D2), 21732179, 1987.

Williams, E. J. and Fehsenfeld, F. C.: Measurement of nitrogen oxide emissions at three North American ecosystems, J. Geophys. Res., 96, 1033-1042, 1991.

Williams, E. J., Guenther, A., and Fehsenfeld, F. C.: An inventory of nitric oxide emissions from soils in the United States, J. Geophys. Res., 97, 7511-7519, 1992.

Xiao, Y., Jacob, D. J., and Turquety, S.: Atmospheric acetylene and its relationship with $\mathrm{CO}$ as an indicator of air mass age, J. Geophys. Res., 112, D12305, doi:10.1029/2006JD008268, 2007.

Yan, X., Ohara, T., and Akimoto, H.: Statistical modeling of global soil $\mathrm{NO}_{\mathrm{x}}$ emissions, Global Biogeochem. Cy., 19, GB3019, doi:10.1029/2004GB002276, 2005.

Yienger, J. J. and Levy II, H.: Empirical model of global soilbiogenic $\mathrm{NO}_{\mathrm{x}}$ emissions, J. Geophys. Res., 100, 11447-11464, 1995. 